\title{
Misuse of Religious titles by self-proclaimed spiritual leaders: Prophets, Apostles, and Popes in South Africa
}

\author{
Jonas Sello Thinane \\ Hebrew Senior Departmental Administrator (SDA) \\ Faculty of Humanities \\ University of the Free State, South Africa \\ jsthinane@gmail.com \\ DOI: https://doi.org/10.46222/pharosjot.102.035
}

\begin{abstract}
In the world of religions, different religious officials are given different titles. Christianity as a religion in the world and in South Africa particularly, has been severely attacked by selfproclaimed spiritual leaders who perform false miracles and abuse titles that have been respected by traditional mainstream churches for decades. These self-appointed spiritual leaders make utilization of these titles either through self-propagating or by accepting them when utilized upon them by their followers. This paper argues that self-appointed spiritual leaders' mere use of these revered religious titles cannot be justified within Christianity's framework. This paper offers a closer look at the literature regarding the use of religious titles such as Prophet, Apostle, and Pope. These religious titles remain very respectable within the Christian religion and are used to honour the role played by both biblical and contemporary Christian leaders. This paper makes three arguments; First, the age of the prophets was washed away by God's written Word in the Holy Bible, so those given this title should be pressed to prove the truthfulness of their prophecies beyond doubt. Second, apostles were those who were eye and ear witnesses to the teachings and resurrection of Jesus. Contemporary apostles must be compelled to defend their apostleship, as is the case in 2 Corinthians 11.Lastly, the title of Pope is traditionally bestowed upon the Catholic Bishop of Rome, the head bishop of the Patriarchate of Alexandria, and other leaders of traditional ecclesial communities. In its entirety, this paper deals with the scientifically neglected aspect within the larger question of the regulation of religions in South Africa.
\end{abstract}

Keywords: Religion, Christianity, Bible, abuse, titles.

\section{Introduction}

South Africa has been credited for the outlook of its Bill of Rights, which promises its citizens, among other things, the constitutional right to religious freedom. In recent years, however, there has been an increase in the abuse of the Christian religion by self-appointed spiritual leaders who make all sorts of false religious claims. What was once the necessary right to religious freedom in South Africa is unexpectedly good on paper and bad in practice because of the behaviour of these self-appointed spiritual leaders or the outward manifestation of such freedom. Their behaviour or these manifestations led the South African Commission for the Promotion and Protection of the Rights of Cultural, Religious and Linguistic Communities (CRL Rights Commission) to propose the regulation of churches. Responding to the CRL Rights Commission recommendation, scholars such as Henrico (2019), Banda (2019), organizations like Freedom of Religion South Africa (FORSA) ${ }^{1}$ and many others, argued that will inadvertently limit the right to freedom of religion. That being said, the details or stories of their abusive behaviour are beyond the scope of this paper. However, scholars such as Pretorius (2004, 2007, 2007), Kgatle (2017, 2020, 2021), Dube, Nkoane and Hlalele (2017), Dube (2019, 2020), Resane (2017), Banda (2019), and Forster (2019), and many others have

\footnotetext{
${ }^{1}$ https://forsa.org.za/why-we-cannot-regulate-religion-part-1/ "FORSA - Why we cannot Regulate Religion"
} 
extensively covered self-appointed spiritual leaders, including views or reactions to recommendations made by the CRL Rights Commission in South Africa.

These self-proclaimed spiritual leaders have not only abused the Christian religion as an institution but also titles that have been respected by traditional mainstream churches for decades. While many scholars have focused on examining the behaviour of self-appointed spiritual leaders, there has been no scientific focus on the abuse of religious titles by these self-appointed spiritual leaders. This paper offers a closer look at the literature regarding the use of religious titles such as Prophet, Apostle, and Pope. With religious abuse on the rise in South Africa, there is an urgent need to consider how appropriate such respectable titles are to be understood and used. This paper makes three arguments concerning these titles; first, it argues that the age of the prophets was washed out of human faculties with the advent of a written Bible. Second, the only true apostles were those who were eye and ear witnesses of the risen Christ, so the apostleship should be reserved only for the twelve apostles of Christ, the Apostle Paul, and a few others who lived in the apostolic age. Finally, it is argued that the universal Church, in particular the Catholic tradition, recognizes Pope Francis as the Catholic Pope, the head bishop of the Patriarchate of Alexandria, and few other respectable leaders of traditional ecclesial communities.

Although some religious and theological scholars have made some attempts to address the issue of regulating religion in South Africa, these attempts did not cover the aspect of abuse of religious titles by self-appointed spiritual leaders as their focus was more on responding to the recommendation the CRL Rights Commission. Years beyond the excellent work by these scholars, the problem of religious abuse remains largely unsolved. This paper attempts to introduce a new aspect of religious title abuse that has been neglected by previous discussions. However, beyond the scope of this paper, there is clearly an increasing need and scope for further research to test the viability of the recommendations made in the concluding observations.

\section{Prophet (Authoritative speaker of God)}

In every religion, the title prophet can be defined/described in the broadest sense as a person who is in contact with the divine being (God in the case of Christianity) and serves as a mediator in the communication between man and the divine being. Self-appointed spiritual leaders have arbitrarily and popularly used this term without proper authorization.

In the Greek language, the term Про́фптns (Prophetes) which consist of two Greek terms Прó

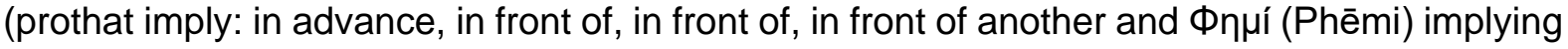

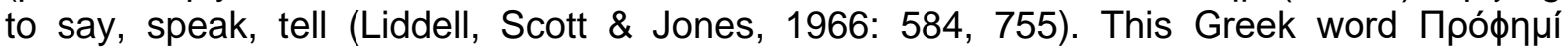
(Prophēmi) means to say beforehand and foretell. In contrast, the word Прочптвía (Propheteia) refers to the gift of interpreting the will of the gods, or the gift of expounding scripture, the gift of public instruction, and the gift of preaching. Прó $\varphi$ Tn' (Prophetes) can be defined equally broadly as one who publicly interpreted the word (of God) (Liddell et al., 1966: 611). While according to Newman (2010), the word Прó who has insight into the will of God and one who possesses the power of inspired utterance (Newman, 2010: 158). According to Neal (2013), this title symbolizes the closer connection between whom it is bestowed and God; hence it was bestowed on religious leaders such as Moses, David, Elisha, and the nameless Prophet from Judah (Neal, 2013: 10). De Bruyn (2013: 73) correctly defines the term prophet as someone who transmits a message directly from God to his people, to whom God has revealed his divine will.

\section{Additional Hebrew words for Prophet}

The first of such terms is (nābi), this term is defined or translated into the English title "Prophet," the literal meaning of the word nābi is "to bubble up" when the meaning of "bubble 
up' is applied in a speech it can mean something to the effect of: 'to declare or to shout.' According to Ward (2009: 124), this term is often used in the Hebrew Bible to describe a prophet and is further associated with the Akkadian verb 'nabu,' which means 'to name or to call' culminating in the 'one who has been called by God.' Pointing towards Deuteronomy 18:18 and Numbers 22:38c, Ward understands the term nābi to mean a prophet as one who speaks only what the Lord has placed in his/her mouth (Ward, 2009: 125). Neal (2013: 8) correctly argues that to avoid unnecessary confusion of what this term could mean, it should be translated as 'the spokesman of God.' Referring to Waltke (2007), Ward (2009: 175) writes: "A nabi designates a person called and designated by God to be his spokesperson. In other words, a prophet is God's human mouth." Hence, it is correct to claim that the Hebrew term (nabi) describes the speaker of God who in spirit utters only the declarations and proclamations of God and not of his own thought or wisdom.

The second Hebrew term associated with Prophet is רֶָה (Roeh) means to see or perceive. Generally, this term is used to describe the 'seer' as someone who imagines the future or who reveals divine secrets. According to Neal (2013: 8), the seer is someone who really sees, and he further claims that the word seer has the authentic meaning for a prophet who receives oracles from God and that it is used more than any other Hebrew term. Ward (2009: 126), regarding this term, writes: "The roeh or seer was one who was gifted with the ability to see that which was hidden from ordinary eyes." From this, it can be concluded with certainty that the definition of the Hebrew term roeh corresponds in principle with the nabi, since both describe someone who in truth receives oracles from God as his spokesman and speaks only for him. This agrees with Neal's argument that a prophet as spokesman for God does not utter words of his own will and thought but is forced to see, hear and speak things that would otherwise remain hidden from him/her (Neal, 2013: 1).

Finally, the Hebrew term trin (Hozeh) is also translated as seeing or perceiving or visionary. Since the exact meaning of this term is rather vague, it does translate into 'prophet' per se, but more of an advisor or one with immense wisdom that qualifies him/her to be an advisor to high offices such as that of the king or priest. However, by virtue of its connection to spirituality and divinity, Hozeh can equally be translated to mean 'prophet.' Neal (2013: 9) writes: "The exact meaning (of Hozeh) may be unclear, but the word refers to a person who receives a vision. Out of the twenty-two occurrences in the Old Testament, eleven of these are connected with the name of a particular person, indicating his office as a prophet." This argument brings one to a conclusion that (Hozeh) (Prophet) in this instance indicates or points to a person who receives their wisdom, insight, and divine messages spiritually from God. Thus, as in the

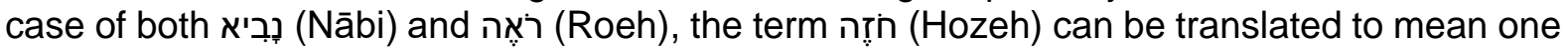
who is the speaker or mouthpiece of God.

Another prophetic title that self-styled spiritual leaders have misused is (ish haelohim), which translates as 'Man of God.' Neal writes: "This title expresses the person's close bond with God." He also emphasizes the respect that should be attached to the use of this title by using it in the corresponding statement, arguing that the Prophet was indeed God's man in the truest sense of the word: through the way in which they lived and carried out their lives their teaching/sermon. To qualify this argument, Neal refers to 1 Timothy $6: 11$, where the Apostle Paul admonishes Timothy, or uses that title, asking him to behave as God's person or a faithful preacher of God's word in front of others (Neal, 2013: 10). Chitando, Gunda and Kügler (2013: 15) further submit that the Phrase 'Man of God' appears in the Bible about 80 times, with 79 of these in the Old Testament and once in the New Testament in 1 Timothy 6:11. They argue that this title is used in the Old and New Testaments to distinguish extraordinary people from others. God chooses those referred to as 'Man of God' to be his representatives, and as such, qualify, or that title indicates the chosen few from a pool of all others (Chitando et al., 2013: 15). Referring to Glover (2006), Chitando et al. (2013: 19) write: "Man of God is an outstanding individual, an 'Übermensch' suggesting an individual who is literally 'above men'." This is a title that places some mortals above other mortals, mainly because of the things that they can accomplish. 
Jeremiah 14:14-16 sternly warns:

They claim to speak for me, but they're lying! I did not even speak to them, neither did I choose them to be my prophets. Their messages come from their worthless dreams, their useless fortune-telling and their own imaginations. Those lying prophets say there will be peace and plenty of food. But I say that those same prophets will die from war and hunger. And everyone who listens to them will be killed, just as they deserve.

Furthermore, the Lord said in Jeremiah 23:25-27 that

These unfaithful prophets claim that I have given them a dream and then they tell lies in my name. But everything they say comes from their twisted minds. How long can this go on? They tell each other their dreams and try to get my people to reject me, just as their ancestors left me and worshiped Baal.

\title{
Biblical prophets
}

Both the prophets of the Old and New Testaments were necessary because the scriptures were not yet completed. Any prophecy carried out of prophetic office was just a revelation from God that came in parts. Apostle Paul argued this in 1 Corinthians 13:9-10 "We do not know everything and our prophecies are not complete. But what is perfect will appear one day, and what is imperfect will then go away."

Now that the last book of the Bible (Revelation) is available to all believers, the age of the true prophets has come to an end, if not long ended. This means the gift of prophets was only relevant in the absence of the bible in its written form, hence Revelation 22:18-19 reads:

\begin{abstract}
Here is my warning to anyone who will hear the prophecies in this book if you add anything to them, God is going to make you suffer all of the terrible problems that are written in this book. If you take anything away from these prophecies, God will not let you into the life-giving tree and holy city described in this book.
\end{abstract}

Furthermore, it is self-evident that Jesus warned in the book of Matthew as he indicated that many false prophets would arise and deceive many by using his name (Matthew 24:11). As De Bruyn (2013: 73) correctly points out, it has always been challenging to determine which Prophet truthfully rep3resented or expressed the true will of God. This form of difficulty existed only before the Bible was declared a true representation of the Word of God. It can be argued that prior to the printed version of the Bible, believers relied more on prophets to proclaim and interpret the word of God. In its written form, the Bible became helpful in assisting communities in distinguishing between true and false prophecy. Beyond this help, the Bible communicated directly with God's people as God's only true word available to all believers. De Bruyn (2013) agrees with Meier (2009) that when prophets like Ezekiel and Jeremiah wrote down prophetic words of God, such a historical event changed the prophecy from oral to written. In this way, the Bible became God's only communication medium for His people .Further, De Bruyn states: "The collection of prophetic texts was seen as "collecting the divine will as it was revealed in the past'”. In his view, eliminated the need for human agency in as far as revelation ions are concerned. In fact, he makes suggestion that the ongoing revelations are superfluous and could be one reason why oral prophets became less and less known during the Second Temple period (De Bruyn, 2013: 76). With all of this in mind, this paper submits that it is inappropriate and daring for any living person, particularly those affiliating to Christian religion 
to call themselves prophets, to speak in the name of the divine, or to pretend to be performing special divine deeds.

\section{Unorthodox Prophets}

Dube (2019: 25) argues that these self-proclaimed prophets are quick to spread their form of the gospel, which deviates completely from Christian teachings and, therefore, ultimately use unorthodox ways to prove their so-called prophecy with false miracles. Furthermore, he argues that they are not prophets, but in his words: business people posing as Christian prophets. With a similar understanding of how quickly these prophets spread like wildfire, Agboadannon and Dossoumou (2018) write in their excellent paper: 'This phenomenon of the new prophets is a poverty-related social dilemma. The New Prophets sprout, spread, and multiply along with the onset of the crisis in the land'. These prophets mushroom like vegetables in the rainy season and are found in cities with many famous Biblical references such as Moses, Joshua, Elijah, Jeremiah, Isaiah, Zechariah, or Abed-Nego. The so-called men of God go to markets, radio stations, television, hospitals, and other public places, hand out leaflets in buses and cars to communicate with the population. They gather people through films and evangelize them. They try by all means to convince people to believe them. Their strategies are used to gain followers for their weekly crowds and then use those followers as their own moneymaking machine (Agboadannon \& Dossoumou, 2018: 15).

What is even more bizarre about these false prophets is that their wives accompany them on this journey of lies. In the context of Zimbabwe, Agboadannon and Dossoumou (2018) quoted the late President of Zimbabwe, President Robert Mugabe, who once criticized the lack of integrity of these false prophets by asking: 'Also in some churches, it is heard that a husband and his wife are prophets and Prophetess! Is that so? Does the Bible say that?' In addition, President Robert Mugabe noted with a frown that there appear to be more prophets than ordinary people in Zimbabwe (Agboadannon \& Dossoumou, 2018: 21).

Believers, especially Christians, should understand that the gift of prophecy is available to all believers and, as such, should not be confused with the important office of the Prophet. Now that canon prophecy has ended, no one can hold any office in prophecy. Just as the apostles of Christ, the prophets of God, formed the basis of faith for all believers, so, like the apostles, prophetic ministry played the fundamental role. Just as the apostolic age has ended, the prophetic age is long gone, and there is not even a true prophet on the surface of this universe. The greatest doctrinal heresy in South Africa comes from the mouths of those who rose to the office of Prophet or are rising to the rank of Prophet. This section concludes that there are no true prophets at all, especially within the Christian religion.

\section{Apostle (Important early teacher of Christianity)}

In reading the Gospels, one learns the narrative that from the start of his public ministry, Jesus Christ chose his close associates or close followers who came to be known or referred to as the "twelve," "the Lord's disciples," and "Apostles." According to John 15, Jesus said to his disciples: "you did not choose me. I chose you and sent you out to produce fruit, the kind of fruit that will last" (John 15:16).

This section will argue that the office of "Apostles" should be reserved only for the twelve apostles of Christ, Apostle Paul, and few additional others who lived within the apostolic age. These are the only people to whom Jesus Christ personally appeared and appointed them as his own apostles. It is with many regrets that in South Africa, the Christian community witnessed ill-advised Christians whom the Apostle Paul warned us against in 2 Corinthians $11: 13$ as false apostles, deceitful people who pretend to be true apostles of Christ. These false apostles are spoken of in Revelation 2: "I know everything you have done, including your hard work and how you have endured. I know you will not put up with anyone who is evil. When 
some people pretended to be apostles, you tested them and found out that they were liars" (Revelation 2:2). These scriptures testify that even among early Christians, as currently in South Africa, there were many who self-proclaimed or wrongly endowed by others the title of Apostle.

\section{Defining the term Apostle}

According to Newman (2010: 23), the Greek word Aтобто入о can be translated into "apostle" or "messenger" this word consists of the preposition amo, which means "from," "by means of,"

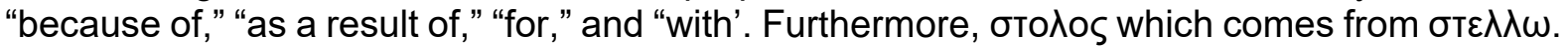
Citing both Geivett and Pivec (2014) and Wuest (1978), Williamson (2016: 10) writes: "The Greek word 'Apostolos from which the English word apostle is derived, may literally be interpreted as 'one who is sent' or to offer a slightly more extensive interpretation, 'to send off' on a commission to do something as one's personal representative, with credentials furnished." This Greek word Атоотоһо ऽ may be translated into terms such as delegate, agent, representative, negotiator or envoy, hence the Rabbis of Jesus time considered it (agency by apostles) so important that it had legal implications. The modern concept that can fully describe this form of agency is "power of attorney."

Accordingly, Burton (1912: 69) wrote: "To say 'the apostle' when speaking of the life of Jesus was, therefore, equivalent to saying 'the twelve." Further, "within the larger company of Jesus' disciples, the twelve constituted an organic body having a definite number and specific function" (Burton, 1912: 69). On the case of those (apostles) other than the twelve, who were included in the group of apostles in particular 'Matthias' Burton (1912: 570) wrote: "by being elected to fill a vacancy, and acquired the title of apostle by virtue of his membership in the twelve."

\section{Conditions for Apostleship}

The condition into apostleship is clearly stipulated in Acts 1:21 when the vacancy was created by the defection and death of Judas Iscariot on his replacement by Matthias: "Therefore it is necessary to select one of the men who have accompanied us the whole time the Lord Jesus went in and out among us (22) beginning from John's baptism until the day Jesus was taken up from us." In support of Burton (1912), Williamson (2016) argues that a person whom to replace Judas following his death was only on the conditions that they must: "have been an eye and ear witness to the risen Christ" (Williamson, 2016: 11). This means for any person to be endowed the title "Apostle," such a person had to at least have personal knowledge of Jesus Christ in his lifetime. Thus, the big and possible question to be answered in this regard will be 'is it at all possible for any person in this age and time to meet this basic biblical qualification for the apostle office? The answer to this is, of course, NO.

Beyond the prerequisite of 'eye and ear witness,' apostleship was validated by accompanying signs and wonders that the true apostles of Christ performed regularly. In support of this argument, Mark 16 reads: "Then the disciples left and preached everywhere. There Lord was with them and the miracles they worked proved that their message was true" (Mark 16:20). For this reason, Apostle Paul, in defending his apostleship before the Church of Corinth he argued: "The signs of a true apostle were performed among you with utmost patience, with signs, wonders and mighty works" (2 Corinthians 12:12). In performing miracles of healing, no health situation was ever too difficult for true apostles to complete. These cases involved forms of physical conditions, body parts recreation, and the resurrection of the dead. At this, one wonders if it will be too much of a challenge to ask the self-proclaimed apostles to hold hands and visit one public hospital, pray and have it emptied. Indeed such a task can be achieved with their miracle-working powers. Jesus Christ personally appointed apostles in order for them to author the New Testament canon, and to validate their appointment, they performed 
true miracles and wonders that could be tested. Thus it is enough to argue that the office of Apostle ceased with the genuine apostolic age.

Further, Williamson (2016) argues that the authority possessed or carried by apostles directly links to the sender (in this case Jesus Christ). Williamson is of the firm view that on their own, apostles are without authority in the absence of authority granted by the sender (Williamson 2016: 13). As his representatives, apostles were appointed by Jesus Christ in order for them to act on his behalf.

At this stage, suffice to argue that no one outside the apostolic age can have accumulated the required credentials (having been the eye and ear witness) of Christ's earthly ministry, which would grant one with authority to be called an "apostle." Williamson (2016: 18) correctly cautions that: "any addition to this unique apostolic group today could risk undermining the testimony of Christ preserved through canonised apostolic writings that have instructed and benefited all believers throughout the Church Age." Williamson (2016: 36) further argues that for anyone to wish to establish apostolic office beyond apostolic age, such persons distort and openly reject the true holy apostolicity. This conduct is detrimental to the well-being of the Church (Williamson, 2016: 36). Quoting Macarthur (2013), Williamson (2016; 37) writes: "A prominent voice within the reformed tradition, observes the danger of reinstating apostles in the contemporary Church, questioning that, if they (claim to) have true 'apostolic authority, then what is to stop them from adding to the Bible?" One can take this question further and ask "with their shallow understanding of Christian history, what will stop them from calling themselves 'Christ(s)?'”

\section{Paul and his apostleship}

Apostle Paul in 1 Corinthians 9:1 asked: "Am I not free? Am I not an apostle? Have I not seen Jesus our Lord? Are you yourselves not my workmanship in the Lord?" Apostle Paul's understanding that his personal experience of Christ determines his occupation of the Apostle's office (Malan, 1976: 58). Burton (1912) correctly argues that the question "Have I not seen Jesus our Lord?" suggests that to have witnessed the resurrection of Christ was a condition of apostleship (Burton, 1912: 571). Thus, the experience of Apostle Paul based on his Damascus vision authenticated his witnessing of Jesus Christ in person. It is important not to dismiss the "eye and ear witness" credential as per the requirements of the new Apostle.

The Apostle Paul argued the integrity and authority of his apostleship based on not having been sent by man but by Jesus Christ, whom he (Apostle Paul) encountered on his way to Damascus. It is precisely for this reason, Burton wrote: "They must also be able to testify to the deeds and words of Jesus before his death and even from the beginning of his public ministry, and carry forward his work as they only could do who knew him well" (Burton, 1912: 582). Thus, it is enough to argue that to appoint Paul as an apostle, Jesus Christ appeared to him, qualifying him to meet the "eye and ear witness" basic requirement like he did to other apostles.

Apostle Paul became an apostle through his responsibility for Gentile churches, including all those churches he did not personally plant; hence to the Galatians, he argued that his apostleship did not come through human selection but from Jesus Christ himself, that God's power made him an apostle to the Gentiles (Galatians 1:1, 2:8). In Colossians 2:1, he said: "I want you to know how hard I am contending for you and for those at Laodicea, and for all who have not met me personally." While Ephesians 2 reads:

You Gentiles are no longer strangers and foreigners. You are citizens with everyone else who belongs to the family of God. You are like a building with the apostles and prophets as the foundation and with Christ as the most 
important stone. Christ is the one who holds the building together and makes it grow into a holy temple for the Lord. And you are part of that building Christ has built a place for God's own spirit to live (Ephesians 2:19-22).

In 1 Corinthians 3:10, Apostle Paul spoke of himself as a wise master builder who is laying a foundation; further, he asked them in 1 Corinthians 9:1, "Am I not an apostle?" These scriptures make it impossible for anyone, particularly those who call themselves Christians, to ignore the fundamental role played by the true apostles of Christ, and this was a unique task performed by true apostles in all of the history of the Church, so it is absurd that the self-styled spiritual leaders in South Africa and elsewhere seem to consider or imagine the possibility of going back in time and laying the foundation stone again.

Beyond the succession of Judas, beyond the appointment of Apostle Paul by Jesus Christ himself, the Bible does not offer any other appointment of apostles. Of course, with the exception of choosing the deacons in Acts 6:1-6, there are no instructions on how to make such an appointment. Beyond the instructions on appointing deacons, elders, or overseers, there is no instruction on how to facilitate the succession of apostles! Thus, it is strange to imagine that the very foundation layers of the Christian faith (true apostles of Christ) who were so concerned about preserving the Christian faith would go out of their way to provide other instructions on other various appointments while ignoring the apostolic succession. It is equally strange that Apostle Paul's letter to Timothy concerned himself with appointments of Bishops and pastors, but yet the appointment of Apostle nothing is said! As founding agents of the Church, the apostles, including Apostle Paul, laid a solid and timeless foundation for the Church of Christ through their "eye and ear witness" of the gospel of Christ and the revelation of God's word.

The Church of Christ has but one foundation that was laid by apostles, and this foundation consisted of concrete faith delivered by the true Apostles to all saints. These Apostles alone laid the Church's foundation, of which the cornerstone is Jesus Christ. However, the timeless foundation laid by the true Apostle with Christ as the cornerstone is more than sufficient for Christians to build the Church. Even though it is the argument of this paper that the Church of Christ has no obligation nor duty to employ other additional foundation layers to lay the foundation again on top of what has been built already. If there is a need at all to restore offices of apostle to make them part of the modern church. Firstly, the self-proclaimed apostles and Christians in general should be made to understand why it has been so important for the apostleship office to be respected. Secondly, it is incumbent upon Christians in general and Christian churches in particular to develop regulatory frameworks that seeks to set criteria for apostleship.

\section{Pope (The head of the Church)}

The word Pope is from the Greek word патाа for father. Pope presides over the central administration of the entire Roman Catholic Church as one of the most prominent traditions or denominations of the three major branches of Christianity (Catholic, 'Eastern' Orthodox, and Protestant) (Rodes, 2015). Although there is a long complicated history of competing claims with much more dynamics by various traditions, which includes the likes of distinguished popes like the Pope of the Coptic Orthodox Church, Pope Tawadros II who became the 118th and current Pope of Alexandria and Patriarch of the See of St. Mark succeeding the late Pope Shenouda III in 2012 (Saad, Riegels \& Westbrook, 2014), due to its limited scope this paper will only present its argumentation using the example of the Catholic Pope.

According to the Catholic teachings, Bishops are the progenies of apostles while the Bishop of Rome (Pope) is the progeny of Apostle Peter and Apostle Paul. Thus, a group of apostles is succeeded by the college of Bishops, for which Saint Peter (head of apostles) is now 
succeeded by Bishop of Rome (Pope) as the head of Bishops. According to McCue (1964), the primacy of the Bishop of Rome is largely derived from his role as the apostolic successor to Saint Peter, to whom primacy was conferred by Jesus, giving him the keys of heaven and powers of 'binding and loosing,' naming him as the 'rock' upon which the Church would be built. Only the Bishop of Rome can be seen as the successor of Saint Peter because their true faith in Christ was witnessed in their city through martyrdom (Papacy | Roman Catholicism, 2019).

According to the synoptic gospels (Matthew, Mark, and Luke), Simon, a mere fisherman, was chosen by Jesus Christ to be his first disciple and subsequently gave him a new name Cephas (Peter), which means 'rock.' This means Jesus Christ himself commissioned St Peter to represent the foundation upon which the unity of apostolic Church is based, it is for this very reason McCue (1964: 161-163) presented sequence saying: "Christ creates the pope, the pope creates the bishops, [and] the bishops create the congregations." Thus, Peter became the first in a line of his contemporaries (true apostles). As such, his status called for a specific authority and respect. According to Acts 2, on Pentecost, after the miracle of languages, Peter was the first to stand together with other apostles.

Further, the Catholic teaches that Saint Peter himself continues the Petrine ministry as the only leader of the apostolic community through the Bishop of Rome (Pope) can give witness to the kind of faith that only Saint Peter confessed and even protects the integrity of such faith (Papacy | Roman Catholicism, 2019). McCue (1964) maintained that continued recognition of Roman Primacy with the bishop of Rome as the only successor to St Peter is to recognize that indeed St Peter was the primate or the foundation of the apostolic Church. This simply means that if anyone suggests or denies that Rome's bishop is the only person to succeed St Peter, such a person denies the Petrine office as the foundation of the apostolic Church (McCue, 1964: 163).

In the past, it might be true that the Pope title could have been accorded to all Bishops, but with evolution of church history, it came to be restricted only to the Bishop of Rome. Following the afore-mentioned restriction, only the bishop of Rome could be seen as the only successor of St Peter upon whom the universal Churches' responsibility and authority lies (McCue, 1964: 163), hence Gregory VII could maintain that there is but one Pope in the whole world. Further, Catholics teach that Jesus Christ himself chose Apostle Peter to be his vicar (one who stands in the pace of another), which is why before electing the new Pope, cardinals subject themselves entirely to the control of the Holy Spirit to choose one whom the Lord Jesus Christ has destined to be his vicar (next Pope). One who will sit as the head of the college of Catholic Bishops, yet at the same time such person is considered to be the servant of the servants of God.

The work of Lundberg (2015) indicates that through the hands of Christian history, few individuals refused to accept the Roman popes and episcopacy or even claim to have been elected as popes either by alternative conclaves or mystical divine intervention. Such individuals would leave the recognised catholic circle and start their own societies, seminaries, and churches to be recognized as popes. According to scholars such as Daly (1952) and Seghers (2006), a Roman priest named Novatian was one of such persons. He, in 251, opposed the election of Pope Cornelius, arguing that Pope Cornelius was too liberal for such an office. Ultimately he received his consecration from three bishops and proclaimed himself the true Pope (Daly, 1952: 33-38). However, the Christian community always rose against such tendencies by condemning them as heretics as they sought to divide the Church (Seghers, 2006: 1-6; Lundberg, 2015: 4).

\section{Pope election}

First and far most, it is important to consider the position of those who gather to elect or vote for a pope. When a pope dies or resigns, a suitable successor is always elected by and from 
amongst the college Cardinals (bishops and Vatican officials below the age of 80years from all over the world) as the electing body of the conclave (papal election). The gathering usually happens at St Peter's Basilica for a Mass summoning the guidance of the Holy Spirit in selecting a new pope. In theory, any catholic male person can be elected Pope, but such a person must first be a bishop before occupying such office (Thavis, 2005: 1-2). According to Kóczy and Sziklai (2015: 6), each cardinal must be a well-known, morally upright, and respectable public figure with known personal behaviour. Once elected into office by a twothirds majority of cardinals, such a person will become the head of the whole universal Church (Kóczy \& Sziklai, 2015: 2).

\title{
South African Pope
}

In South Africa, the founder and leader of the Gabola Church, Tsietsi Makiti, is called Pope by his followers, who follow the example of their leader in claiming access to God by consuming large amounts of alcohol during services ${ }^{2}$. According to Dube (2019), Tsietsi found this Church as early as 2017 (Dube, 2019: 2). In recent times ordinary Catholics who thought there was only one Pope in the whole world would not hide their shock as they heard an excessive drinker being called "pope of Africa." The term "Gabola" is a Setswana word for drinking. Consistent with its name, Makiti argued that the Gabola church which in his own words "accommodate the so-called drunkards" who were rejected from colonial churches, believes that its congregants must consume excessive alcohol during services in order for them to connect with God (BBC News, 11 August 2020). This Church uses taverns for worship service with the tavern owners automatically become pastors and bishops while their customers become congregants (Dube, 2019: 2; Luhanga, 2021). Relaying on Jared (2017), Dube (2019) quoted a member of that Church who praised its sense of freedom, saying: "Gabola is a good church, we are free here, [and] we are not judged. We do all we want, and such freedom is not there in other churches of the congregants". In Meldrum (2018), Makiti was quoted saying:

\begin{abstract}
We are a church for those who have been rejected by other churches because they drink alcohol, Gabola Church is established to redeem the people who are rejected, who are regarded as sinners. We drink for deliverance. We are drinking for the Holy Ghost to come into us.... Our aim is to convert bars, taverns and shebeens into churches, and we convert the tavern-owners into pastors (Meldrum, 2018: Online).
\end{abstract}

It should be frowned upon when people like Tsietsi Makiti who do not even meet the required moral integrity standards to assume such universal responsibility by proclaiming themselves as holders of such a high and holy office. A person who fails to safeguard the Christian faith's only integrity cannot be allowed to call himself Pope of Africa. In fact, regarding the Church of Corinth, McCue (1964) goes further to emphasise, saying: "It is the bishop of Rome, and not merely the Roman Christian community, who is exercising authority over the Church at Corinth (McCue, 1964: 165). Impostors such as Tsietsi Makiti truly threaten the integrity of Christian religion that the true Pope and his order of Bishops defended in the many years that various forces threatened the existence of Christianity. It is indeed an insult to the Catholic tradition for anyone to consider or proclaim themselves anything closer to the successor of Saint Peter, head of the college of Bishops and servant of the servants of God.

If Catholics refer to the Pope as "his Holiness" or "Holy Father," does this mean the likes of Tsietsi Makiti are to be seen in the same light? However, these incidents are an indication that the true Church is under attack. When the office of the supreme pontiff is threatened in this

\footnotetext{
${ }^{2}$ South Africa: Gabola Church connects with God by drinking alcohol - https://www.bbc.com/news/av/worldafrica-53724453
} 
manner, it remains duty-bound for every Christian, Catholic, in particular, to rise to the complete defense of the Church of Christ and the Papacy institution. The current Catholic Pope recognized in the whole world is none other than Pope Francis, who became the only head of the Catholic Church since the resignation of Pope Benedict XVI on 28 February 2013 (Ott, 2019: Online).

\section{Recommendations}

Firstly, It will be hard for anyone to easily dismiss the relevance and importance of Biblical verses such as Ephesians 4:11-12 which categorically states: "And He gave some as apostles, and some as prophets, and some as evangelists, and some as pastors and teachers, for the equipping of the saints for the work of service, to the building up of the body of Christ." However, it is important that such should be read along Biblical provisions such as in 1John 4:1 which encourage believers not to believe every spiritual claim, but to test them to confirm if they are indeed from God or based upon false prophecies. Secondly and in addition to this, if at all there is a need to reintroduce or restore prophet and apostle offices, such process must be properly regulated by all relevant stakeholders of various religions in general and by authoritative Christian structures in particular as it is the case with Roman Catholic, Orthodox and other distinguished traditions.

Secondly, consistent with the recommendation of the CRL Rights Commission to have religion regulated in South Africa, this paper recommends that when restricting harmful activities on behalf of religion, religious organizations in collaboration with the South African government must establish registration measures that regulate the use of respected religious titles. These measures must be made known to the public in order to avoid false claims by individuals. This will allow the public in general, and religious followers in particular, to review the status of selfappointed leaders. This will further help religious organizations to publicly define their leadership criteria and the truth about their various dogmas against false claims.

\section{Conclusion}

This paper advanced and substantiated three theological arguments, which are as follows: Firstly, that the age of the prophets has been washed away from human faculties by the advent of a written Bible as the only true Word of God. Secondly, that since apostles were those who were eye and ear witnesses to the teachings and resurrection of Jesus, Christian churches should develop strict regulatory frameworks which will compel the contemporary apostles to defend their apostleship, as is the case in 2 Corinthians 11. Lastly, it argued that the universal Church or the Christian community in its entirety has one Pope who is also known as the supreme pontiff and that such a person is currently no one but Pope Francis, who has occupied the papacy since 2013. This paper has recommended that all religions, and Christian churches in particular should consider collaborating with the state in finding and developing measures that will restore religious integrity. Throughout these developments, religious organisations will remain autonomous with the state merely as the administrator. Ultimately, these measures will curb practices that continue to misuse or abuse the constitutionally guaranteed freedom of religion in South Africa.

\section{References}

Agboadannon, K.A.D. \& Dossoumou, A.M. (2018). Fake Prophets and Evangile for Sale in Amma Darko's Not without Flowers. International Journal on Studies in English Language and Literature, 6(6), 15-29.

Banda, C. (2019). Redefining religion? A critical Christian reflection on CRL Rights Commission's proposal to regulate religion in South Africa. Verbum et Ecclesia, 40(1), 1-11. 
BBC News. (2020). We connect with God under the influence of liquor. .[Available online at https://www.bbc.com/news/av/world-africa-53724453] (Retrieved Sept 10, 2021).

Bible Society of South Africa (2003). Holy Bible : Contemporary English Version. Cape Town: Bible Society of South Africa.

Burton, E.D. (1912). The Office of Apostle in the Early Church. The American Journal of Theology, 16(4), 561-588.

Chitando, E., Gunda, M.R. \& Kügler, J. (2013). Prophets, profits and the Bible in Zimbabwe: Festschrift for Aynos Masotcha Moyo (Vol. 12). Netherlands: University of Bamberg Press.

Daly, C.B. (1952). Novatian and Tertullian. Irish Theological Quarterly, 19(1), 33-43.

De Bruyn, J. (2013). And the Word became prophet. Old Testament Essays, 26(1), 70-85.

Dube, B. (2019). Is Gabola a decolonial church or another trajectory of freedom of religion in post-colonial South Africa? Rethinking ethical issues in religious praxis. Religions, 10(3), 167.

Dube, B. (2020). Can religion (un) zombify? The trajectories of psychic capture theology in postcolonial South Africa. HTS Theological Studies, 76(3), 1-7.

Dube, B., Nkoane, M.M. \& Hlalele, D. (2017). The Ambivalence of Freedom of Religion, and Unearthing the Unlearnt Lessons of Religious Freedom from the Jonestown Incident: A Decoloniality Approach. Journal for the Study of Religion, 30(2), 330-349.

Forster, D. (2019.). Why South Africans are prone to falling for charlatans in the church. [Online]. https://theconversation.com/why-south-africans-are-prone-to-falling-for-charlatansin-the-church-112879 (Retrieved Sept 11, 2021).

Henrico, R. (2019). Proselytising the Regulation of Religious Bodies in South Africa: Suppressing Religious Freedom? Potchefstroom Electronic Law Journal, 22, 1-27.

Kgatle, M.S. (2017). The unusual practices within some Neo-Pentecostal churches in South Africa: Reflections and recommendations. HTS: Theological Studies, 73(3), 1-8.

Kgatle, M.S. (2020). New paradigms of pneumatological ecclesiology brought about by new prophetic churches within South African Pentecostalism. Verbum et Ecclesia, 41(1), 40.

Kgatle, M.S. (2021). Pentecostalism and cultism in South Africa. Cham: Springer.

Kóczy, L.Á. and Sziklai, B. (2015). Electing the pope. Homo Oeconomicus, 32(1), 101-116.

Liddell, H.G., Scott, R. and Jones, H.S. (1966). A Greek-English lexicon. [Hauptbd.]. Oxford: Clarendon Press.

Liturgy Training Publications (1994). The New Testament : contemporary English version. Chicago, II: Liturgy Training Publications.

Luhanga, E. (2021). Gabola anthem for national anthem! says Pope Tsietsi. .[Available online at https://scrolla.africa/gabola-anthem-for-national-anthem-says-pope-tsietsi/] (Retrieved Sept 10, 2021).

Lundberg, M. (2015). Modern Alternative Popes. [Available from https://www.divaportal.org/smash/get/diva2:873666/FULLTEXT01.pdf] (Retrieved Sept 10, 2021).

Malan, F.S. (1976). The relationship between Apostolate and Office in the theology of Paul. Neotestamentica, 10(1), 53-68.

McCue, J.F. (1964). The Roman Primacy in the Second Century and the Problem of the Development of Dogma. Theological Studies, 25(2), 161-196.

Meldrum, A. (2018). New South African church celebrates drinking alcohol. .[Available online at https://apnews.com/article/ap-top-news-africa-south-africa-international-news-religionbb3a30956b334f4984d5558f48a9019a] (Retrieved Sept 10, 2021). 
Neal, R. (2013). Prophets and Prophetism In the Hebrew Bible Contents. www.academia.edu. .[Available online at https://www.academia.edu/8491003/Prophets_and_Prophetism_In_the_Hebrew_Bible_Cont ents] [Accessed 18 Oct. 2021].

New, I. (2005). Seed : CEV Bible. Wellington N.Z.: Bible Society In New Zealand.

Newman, B. (2010). Greek-English Dictionary of the NT, Concise. .[Available online at https://accordancebible.com/product/greek-english-dictionary-of-the-nt-concise-by-barclaynewman-2010-revision/] (Retrieved Sept 28, 2021).

Ott, T. (2019). Why Pope Benedict XVI Resigned. https://www.biography.com/news/popebenedict-resignation (Retrieved Sept 11, 2021).

Papacy | Roman Catholicism. (2019). Encyclopædia Britannica. .[Available online at https://www.britannica.com/topic/papacy] (Retrieved Sept 10, 2021).

Pretorius, H.P. (2007). Seemingly harmless new Christian religious movements in South Africa pose serious threats of spiritual abuse. HTS Teologiese Studies/Theological Studies, 63(1), 261-281.

Pretorius, S. (2011). Spiritual abuse under the banner of the right to freedom of religion in religious cults can be addressed. Acta Theologica, 31(2), 219-240.

Pretorius, S.P. (2004). Mind control: The secret weapon utilised by religious cults to control their followers. Koers: Bulletin for Christian Scholarship= Koers: Bulletin vir Christelike Wetenskap, 69(4), 607-621.

Resane, K. (2017). And they shall make you eat grass like oxen (Daniel 4:24): Reflections on Recent Practices in some New Charismatic Churches. Pharos Journal of Theology, 98. .[Available online

https://www.pharosjot.com/uploads/7/1/6/3/7163688/article_10_vol_98_2017.pdf]

(Retrieved Sept 11, 2021).

Rhodes, R. (2015). The complete guide to Christian denominations. Eugene, Oregon: Harvest House Publishers.

Saad, S.M., Riegels, N.S. and Westbrook, D.A. (2014). Traditions of Selecting Coptic

Patriarchs over Two Millennia. Journal of Coptic Studies, [online] 16, pp.139-153.

Available at: https://poj.peeters-leuven.be/content.php?url=article\&id=3066725

(Retrieved 26 Oct. 2021).

Seghers, J. (2006). Papal Primacy: A Historical Perspective. .[Available online at https://d2y1pz2y630308.cloudfront.net/20238/documents/2018/4/PapalPrimacy-

AHistoricalPerspective.pdf] (Retrieved Sept 11, 2021).

Thavis, J. (2005). How a new pope is chosen.[Available online at https://www.usccb.org/about/leadership/holy-see/benedict-xvi/upload/How-a-Pope-isChosen.pdf] (Retrieved Sept 10, 2021).

Ward, Jr, H.D. (2009). On defining a prophet: a theological-ethical study of the Balaam narratives of Numbers 22-24 (Doctoral dissertation). Stellenbosch: Stellenbosch University.

Williamson, N. (2016). A critique of the New Apostolic Reformation (NAR) movement's claim that the lost office of "apostle" has been fully restored and should be acknowledged by today's Church. [Available online at https://www.academia.edu/27464056/A_critique_of_the_New_Apostolic_Reformation_NAR_ movements_claim_that_the_lost_office_of_apostle_has_been_fully_restored_and_should_b e_acknowledged_by_todays_Church (Retrieved Sept 28, 2021)]. 